\title{
Xylitol Production from Oil Palm Empty Fruit Bunches (OPEFB) Via Simultaneous Enzymatic Hydrolysis and Fermentation Process
}

\author{
Efri Mardawati *,1, Nadya Maharani ${ }^{2}$, Dwi Wahyudha Wira ${ }^{3}$, Budi Mandra \\ Harahap 1, Triyuliana ${ }^{2}$, and Een Sukarmina ${ }^{2}$ \\ 1Department of Agro-industrial Technology, Faculty of Agro-industrial Technology \\ Universitas Padjadjaran, Jatinangor, Bandung, Indonesia. \\ ${ }^{2}$ Department of Food Technology, Faculty of Agro-industrial Technology, Universitas \\ Padjadjaran, Jatinangor, Bandung, Indonesia \\ 3Department of Veterinary Medicine, Faculty of Medicine, Universitas Padjadjaran, \\ Jatinangor, Bandung, Indonesia \\ Email: efri.mardawati@unpad.ac.id*
}

\begin{abstract}
Oil palm empty fruit bunches (OPEFB) are the waste of the palm oil processing and a lignocellulosic biomass that can be used as raw material for xylitol production. In this research, bioconversion of xylitol using the Simultaneous Saccharification and Fermentation (SSF) process in one reactor with short time and could save the cost. Pretreatment requires to degrade the lignin compound with thermal pretreatment. Hydrolysis of OPEFB performs enzymatically by commercial xylanase enzyme that is Cellic Htec2 and continued with fermentation by yeast Debaryomyces hansenii. The research used experimental and descriptive analysis that covers of variation of OPEFB substrate concentration $(7.5 \%, 10 \%, 15 \%, 20 \%)$ on specific growth rate $(\mu)$, the yield of xylitol and substrate utilization. The results showed that an increase of OPEFB substrate concentration affected by the increasing of specific growth rates $(\mu)$ are $0.091 / h$, $0.094 / h, 0.095 / h$ and $0.126 / h$. It also affected to the decreasing of xylitol yield on 42 hours fermentation are $0.201 \mathrm{~g} / \mathrm{g} ; 0.189 \mathrm{~g} / \mathrm{g} ; 0.170 \mathrm{~g} / \mathrm{g}$; and $0.104 \mathrm{~g} / \mathrm{g}$.
\end{abstract}

Keywords: OPEFB, SSF, Xylitol, Solid loading, Specific cell growth rate $(\mu)$

\section{INTRODUCTION}

Indonesia as the world's top producer and exporter of palm oil unavoidably contributes to large waste disposal from the activities of palm oil production. These wastes still contain valuable constituents that can be converted to various products. One of them is oil palm empty fruit bunches (OPEFB) generated from oil palm mill, particularly in Indonesia around 6 million ton OPEFB per year [1]. A major component of OPEFB was lignocellulose primarily consisted of $45 \%$ cellulose (homopolymer of glucose), $\quad 25-30 \% \quad$ hemicellulose (heteropolymer of C5 and C6 sugars), 25$30 \%$ lignin and extractive compounds [2]. Cellulose and hemicellulose could be hydrolyzed enzymatically to fermentable sugars. The major sugar in hemicellulose of OPEFB was xylose $(82.20 \%)$ as substrate of xylitol production [3].

Xylitol, one of the polyol sugars, has numerous benefits in particular for sugar substitution in both food and pharmaceutical application because the degree of sweetness in xylitol slightly equals to sucrose. Xylitol did not require insulin to regulate metabolism in a human's body [4]. Thus, people with diabetes could consume this sugar. Moreover, this sugar also was able to prevent dental caries, so considerably applied in toothpaste.

Hydrolysis and fermentation for xylitol production were commonly carried out separately or namely separate hydrolysis and fermentation (SHF). However, this 
technique was ineffectively implemented particularly in larger scale because of longer process and more reactors needed. Therefore, simultaneous saccharification and fermentation (SSF) was the proper approach to tackle this problem [4]. In addition, research with subjected to xylitol production via SSF was still inconsiderably reported, so this method was conducted in this research.

One of the essential factors influencing xylitol formation was solid loading concentration of raw materials. Optimization was needed to increase xylose produced, so more xylitol could be obtained [3]. Yeast could optimally utilize xylose in the limited substrate [6]. However, the high substrate also could inhibit the process because more inhibitors were released or formed during pretreatment [7]. Accordingly, this research studied the effect of solid loading concentration on xylitol production with the method of SSF from OPEFB with the aim to obtain high xylitol yield.

\section{MATERIAL AND METHODS}

\subsection{Raw Materials}

In this research, OPEFB was collected from Oil Palm Mill PTPN 8, Cikasungka located in Bogor, Indonesia. OPEFB was chopped and then repeatedly washed with tap water to reduce all impurities adhering on the surface. Clean OPEFB was then dried using the oven at $105{ }^{\circ} \mathrm{C}$ for $24 \mathrm{~h}$ and followed by grinding using disc mill. OPEFB particles were sieved to equate its size at below 80 meshes.

Lignocellulose in OPEFB identified by the following method of [8,9] was composed of $39.47 \pm 0.74 \%$ cellulose, $17.31 \pm 0.56 \%$ hemicellulose, $23.26 \pm 1.00 \%$ lignin with water and ash content was $4.85 \pm 0.10$ and $4.82 \pm 0.16 \%$, respectively.

\subsection{Pretreatment}

Prior to hydrolysis, OPEFB was pretreated through autohydrolysis method. Ratio of OPEFB and acetic acid buffer $(\mathrm{pH}$ 5.0) was varied with concentration of 7.5; $10 ; 15 ; 20 \%(\mathrm{w} / \mathrm{v})$. OPEFB was heated using the autoclave and kept at $121{ }^{\circ} \mathrm{C}$ for 15 minutes.

\subsection{Xylitol Production}

\subsubsection{Inoculum Preparation}

Yeast used in this research, Debaryomyces hansenii ITBCC R85, was obtained from Microbiology and Bioprocess Technology, Department of Chemical Engineering, Institut Teknologi Bandung. Inoculum medium consisted of carbon source (2 $\mathrm{g}$ xylose), pre-sterilized inorganic salt solution $\left(0.94 \mathrm{~g}\left(\mathrm{NH}_{4}\right)_{2} \mathrm{SO}_{4}, 0.25 \mathrm{~g}\right.$ $\mathrm{KH}_{2} \mathrm{PO}_{4}, \quad 0.005 \quad \mathrm{~g} \quad \mathrm{CaCl}_{2} .2 \mathrm{H}_{2} \mathrm{O}, \quad 0.05 \mathrm{~g}$ $\mathrm{MgSO}_{4} .7 \mathrm{H}_{2} \mathrm{O}, 0.05 \mathrm{~g}$ citric acid, $0.0035 \mathrm{~g}$ $\mathrm{FeSO}_{4 .} .7 \mathrm{H}_{2} \mathrm{O}, 0.00092 \mathrm{~g} \mathrm{MnSO}_{4} .4 \mathrm{H}_{2} \mathrm{O}, 0.0011$ $\mathrm{g} \mathrm{ZnSO}_{4} .7 \mathrm{H}_{2} \mathrm{O}, 0.0001 \mathrm{~g} \mathrm{CuSO}_{4} .5 \mathrm{H}_{2} \mathrm{O}, 0.0002$ g $\mathrm{CoCl}_{2} .6 \mathrm{H}_{2} \mathrm{O}, 0.00013 \mathrm{~g} \mathrm{Na} \mathrm{MoO}_{4} \cdot 2 \mathrm{H}_{2} \mathrm{O}$, $0.0002 \mathrm{~g} \mathrm{H}_{3} \mathrm{BO}_{3}, 0.00035 \mathrm{~g} \mathrm{KI}, 0.00005 \mathrm{~g}$ $\left.\mathrm{Al}_{2}\left(\mathrm{SO}_{4}\right)_{3}\right)$, and filtered sterilized vitamin solution $(0.01 \mathrm{~g}$ Myo-inositol, $0.002 \mathrm{~g} \mathrm{Ca}-$ pantothenate, $0.0005 \mathrm{~g}$ Thiamine hydrochloride, $\quad 0.0005 \mathrm{~g}$ Pyridoxal hydrochloride, $0.0005 \mathrm{~g}$ Nicotinic acid, $0.0001 \mathrm{~g}$ Aminobenzoic acid, $0.00001 \mathrm{~g} \mathrm{D}-$ biotin), and $100 \mathrm{~mL}$ of distilled water [10]. Yeast culture was propagated using a rotary shaker incubator at $30^{\circ} \mathrm{C}$ for 2 days or until reaching minimum cell concentration approximately $10^{6} \mathrm{cell} / \mathrm{mL}$.

\subsubsection{Simultaneous Saccharification and Fermentation}

Pretreated OPEFB for each solid loading was hydrolyzed by $10 \mathrm{~mL}$ Cellic HTec 2 (Novozyme) with its activity of 750 $\mathrm{U} / \mathrm{mL}$ measured with the method of [11]. Enzymatic hydrolysis was performed using a rotary shaker incubator at $60{ }^{\circ} \mathrm{C}$ with agitation of $150 \mathrm{rpm}$. Value of $\mathrm{pH}$ was controlled with acetic buffer ( $\mathrm{pH}$ 5.0).

Hydrolysis was stopped after $72 \mathrm{~h}$ and hydrolysate was collected for monomeric sugar analysis. Around $150 \mathrm{~mL}$ another macro- and micro-nutrients [3] was added and $100 \mathrm{~mL}$ prepared inoculum of $D$. hansenii was subsequently inoculated into the hydrolysis flask. Hydrolysis incorporated with batch fermentation was continued at $30{ }^{\circ} \mathrm{C}$ and $150 \mathrm{rpm}$ for $96 \mathrm{~h}$. Every $3 \mathrm{~h}$ broth was sampled and analyzed to identify the concentration of cell, remained sugar, 
product, and acetic acid. Several parameters were observed further, viz. specific cell growth rate $(\mu)$, yield $(\mathrm{YP} / \mathrm{S}, \mathrm{YP} / \mathrm{X}$, and YX/S), and xylose utilization.

\subsection{Analytical Method}

To determine dry weight cell (dcw), turbidity level of biomass expressed in optical density (OD) for each sample was measured with spectrophotometer UV-VIS and regressed to a standard curve (dcw and OD). On the other hand, glucose, xylose, xylitol, and acetic acid was analyzed using HPLC with BioRad Aminex HPX-87X column at $60{ }^{\circ} \mathrm{C}$, using eluent of $5 \mathrm{mM} \mathrm{H} 2 \mathrm{SO} 4$, and equipped with Refractive index detector set at $40{ }^{\circ} \mathrm{C}$. Empower ${ }^{\mathrm{TM}}$ Chromatography Data Software (Waters Corp., Milford, MA) was used for processing the data. As supporting data, assessment of OPEFB surface before and after a series of the process was observed using scanning electron microscope (SEM).

\subsection{Data Interpretation}

Growth of microorganisms was parameterised as the specific growth rate that was calculated from biomass concentration data during the logarithmic phase, following Equation 1.

$$
\frac{d X}{d t}=\mu \mathrm{X}
$$

Performance of the fermentation was parameterised by yield which is described as the ratio of formed product to used substrate and cell following Equation 2 and 3.

$$
\begin{aligned}
Y_{\mathrm{P} / \mathrm{S}} & =\frac{\left(P-P_{0}\right)}{-\left(S-S_{0}\right)} \\
\mathrm{Y}_{\mathrm{P} / \mathrm{X}} & =\frac{\left(P-P_{0}\right)}{\left(X-X_{0}\right)}
\end{aligned}
$$

Where:

$$
\begin{aligned}
& \mathrm{P} \quad=\text { xylitol product concentration }(\mathrm{g} / \mathrm{L}) \\
& \mathrm{t}=\text { total fermentation time }(\mathrm{h}) \\
& \mathrm{Y}_{\mathrm{P} / \mathrm{S}} \quad \text { = product-from-substrate yield } \\
& \text { ( } \mathrm{Y}_{\mathrm{P} / \mathrm{S}}=\mathrm{g} \text {-xylitol } / \mathrm{g} \text {-xylose), } \\
& \left(\mathrm{Y}_{\mathrm{X} / \mathrm{S}}=\mathrm{g} \text {-biomass } / \mathrm{g} \text {-total substrate }\right) \\
& \mathrm{Y}_{\mathrm{P} / \mathrm{X}} \quad=\text { product-from-cell yield (g-xylitol/g- } \\
& \text { cell) } \\
& \mathrm{X}=\text { cell concentration }(\mathrm{g} / \mathrm{L}) \\
& \mu \quad=\text { specific growth rate }\left(\mathrm{h}^{-1}\right)
\end{aligned}
$$

$\mathrm{S} \quad=$ substrate concentration $(\mathrm{g} / \mathrm{L})$

\section{RESULTS AND DISCUSSION}

\subsection{Influence of Solid Loading on Monomeric Sugar Composition in The Hydrolysate}

The time profile of two major monomeric sugars in hydrolysate, xylose, and glucose, for each solid loading was shown in Fig. 1. The increase of OPEFB solid loading could elevate both sugar concentration obtained showing that no substrate inhibition occurred in the range of solid loading from $7.5 \%$ to $20 \%$. After 72 hours of hydrolysis, maximum xylose $(1.628$ $\mathrm{g} / \mathrm{L})$ was reached with $20 \%$ OPEFB solid loading. Glucose was still formed in this process since apart from xylanase, cellulase also was detected in Cellic HTec2. Moreover, glucose concentration was always higher than that of xylose. This data showed that higher performance of enzyme in Cellic HTec2 was possessed by cellulase instead of xylanase. In addition, cellulose content in OPEFB used in this research was doubled from hemicellulose. The maximum glucose achieved was approximately $4.5 \mathrm{~g} / \mathrm{L}$ glucose from 20\% OPEFB solid loading after $96 \mathrm{~h}$ hydrolysis.

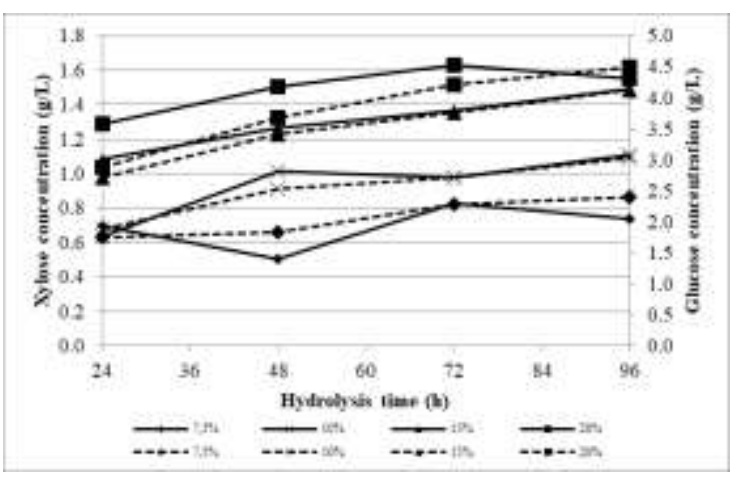

Figure 1. Xylose (solid line) and glucose (dash line) concentration released to hydrolysate for each OPEFB solid loading

Longer hydrolysis time also could increase sugar concentration because the higher substrate concentration was used, the more active side of the enzyme was bonded to the substrate [3]. This interaction formed enzyme and substrate complex. 
Breakage of this bond then occurred and products, monomeric sugars, was released.

\subsection{Influence of Solid Loading on Specific Cell Growth Rate}

Cell growth curve of $D$. hansenii for various initial OPEFB concentration was presented in Fig. 2 In general, a cell of D. hansenii grown in OPEFB medium took place three phases of growth. Firstly, the lag phase occurred at a shorter time for $7.5 \%$ OPEFB solid loading (from 0 to $4 \mathrm{~h}$ ) and at a longer time for solid loading of $10 \%, 15 \%$, and $20 \%$. This result showed that $D$. hansenii could be more adaptable in medium with lower OPEFB solid loading. The occurrence of cell adaptation in a new medium was caused by the need for yeast time to synthesize enzyme for converting the nutrition to essential compounds for its growth. According to [12], lag phase duration was influenced by yeast medium types, a physical condition in medium, and inoculum amount. The higher initial yeast was inoculated, the shorter lag phase time was reached [13].

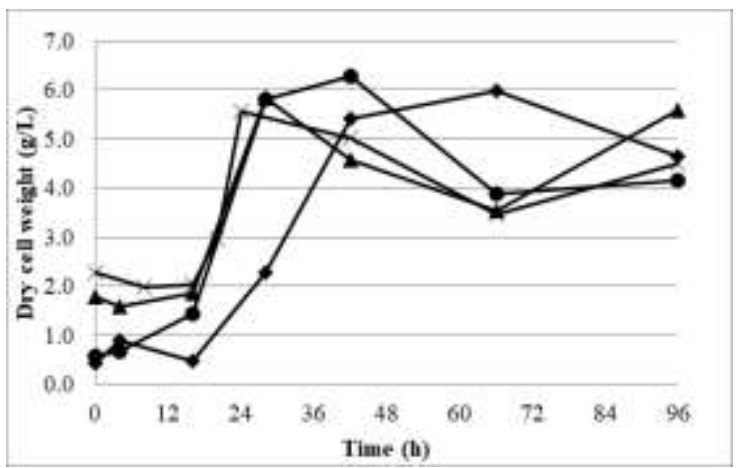

Figure 2. Cell growth profile for each OPEFB solid loading (circles, cloves, triangles, and rectangles represent $7.5 \%, 10 \%, 15 \%$, and $20 \%$ OPEFB solid loading concentration, respectively)

The second phase, the logarithmic phase, was initiated after $4 \mathrm{~h}$ fermentation and stopped at $28 \mathrm{~h}$ for $7.5 \%$ of solid loading. For the other solid loading concentration, viz. $10 \%, 15 \%$, and $20 \%$, this phase was started from $16 \mathrm{~h}$ to $42 \mathrm{~h}, 16$ to $28 \mathrm{~h}$, and $16 \mathrm{~h}$ to $24 \mathrm{~h}$ fermentation, respectively. Overall, the data was concluded that the shorter logarithmic phase was possessed at the highest OPEFB solid loading. On the contrary, this solid solid loading had the highest $\mu$ around $0.126 \mathrm{~h}^{-1}$ as presented in Table 1 . Interestingly, the value of $\mu$ increased over the increase of solid loading concentration. [14] stated that $\mu$ was significantly influenced by initial substrate concentration used for yeast growth.

Table 1. The specific cell growth rate for each OPEFB solid loading

\begin{tabular}{cc}
\hline OPEFB Solid Loading (\%) & $\boldsymbol{\mu}\left(\mathbf{h}^{-\mathbf{1}}\right)$ \\
\hline 7.5 & 0.091 \\
10 & 0.094 \\
15 & 0.095 \\
20 & 0.126 \\
\hline
\end{tabular}

The following phase, stationary phase signified with no significant change of dry cell weight (Fig. 2) was started at $28 \mathrm{~h}$ fermentation for $7.5 \%$ and $15 \%$ OPEFB solid loading, at $42 \mathrm{~h}$ fermentation for $10 \%$ OPEFB solid loading, and at $24 \mathrm{~h}$ fermentation for 20\% OPEFB solid loading. After $96 \mathrm{~h}$ fermentation, yeast was still in stationer phase and had not been in the death phase.

\subsection{Xylitol Fermentation via Simultaneous Saccharification and Fermentation (SSF)}

According to Table 2, the highest xylitol yield was obtained when fermentation was performed at $42 \mathrm{~h}$ using the lowest solid loading concentration (7.5\%), around $0.20 \mathrm{~g}$ xylitol/g xylose. However, after $96 \mathrm{~h}$ fermentation xylitol yield declined for all solid loading concentration, except for the concentration of $20 \%$ yield of xylitol increased up to $0.19 \mathrm{~g} / \mathrm{g}$.

This result showed that xylitol released was still metabolized by yeast, so its yield reduced. Even though the highest xylitol yield was achieved at $7.5 \%$ solid loading, not all xylose was completely consumed. Only $85 \%$ of xylose was used by yeast for growth, maintenance, and product formation. Conversely, yeast utilized all xylose in hydrolysate for solid loading of over 7.5\%. 
Table 2. Kinetics parameters of fermentation

\begin{tabular}{|c|c|c|c|c|c|c|c|}
\hline \multirow{2}{*}{$\begin{array}{c}\text { Solid } \\
\text { loading } \\
(\%)\end{array}$} & \multirow{2}{*}{$\begin{array}{c}\text { Xylose } \\
\text { utilization } \\
(\%)\end{array}$} & \multicolumn{2}{|c|}{$Y_{x / s}(g / g)$} & \multicolumn{2}{|c|}{$\mathrm{Y}_{\mathrm{p} / \mathrm{s}}(\mathrm{g} / \mathrm{g})$} & \multicolumn{2}{|c|}{$\mathrm{Y}_{\mathrm{p} / \mathrm{x}}(\mathrm{g} / \mathrm{g})$} \\
\hline & & $\mathrm{t}_{42 \mathrm{~h}}$ & $\mathrm{t}_{96 \mathrm{~h}}$ & $\mathrm{t}_{42 \mathrm{~h}}$ & $\mathrm{t}_{96 \mathrm{~h}}$ & $\mathrm{t}_{42 \mathrm{~h}}$ & $\mathrm{t}_{96 \mathrm{~h}}$ \\
\hline 7.5 & 86 & 38.25 & 24.48 & 0.20 & 0.07 & 0.005 & 0.003 \\
\hline 10 & 100 & 35.05 & 25.24 & 0.19 & 0.00 & 0.005 & 0.00 \\
\hline 15 & 100 & 14.85 & 17.78 & 0.17 & 0.00 & 0.011 & 0.00 \\
\hline 20 & 100 & 14.33 & 10.84 & 0.10 & 0.19 & 0.007 & 0.017 \\
\hline
\end{tabular}

The yield of biomass also was maximally obtained at $7.5 \%$ OPEFB solid loading after $42 \mathrm{~h}$ fermentation. From that time to $96 \mathrm{~h}$ fermentation, biomass yield decreased for all solid loading concentration, except at $15 \%$. This result indicated that the number of the cell had declined over that time. In addition, according to Table 2, a higher yield of biomass than that in xylitol yield showed that more xylose was consumed for cell formation and propagation than for product formation.

As compared to separate hydrolysis and fermentation (SHF) method reported by [7] using the same raw material and its solid loading concentration that could obtain $0.242 \mathrm{~g} / \mathrm{g}$ xylitol, lower xylitol yield $(0.19$ $\mathrm{g} / \mathrm{g}$ ) with the method of SSF in this research was obtained. This result also was in favor of research data reported by [15] using bagasse as raw material and approached of SHF and SSF with a yield of $0.235 \mathrm{~g} / \mathrm{L}$ and $0.225 \mathrm{~g} / \mathrm{L}$, respectively. Hence, the presence of remained OPEFB solid after hydrolysis could not give extra nutrition for yeast, but it could inhibit the following process, fermentation.

Profile of xylitol formation was shown in Fig. 3. Xylitol was formed at $42 \mathrm{~h}$ fermentation or at the stationary phase for OPEFB solid loading of $7.5 \%, 10 \%$, and $15 \%$. However, for higher solid loading (20\%) xylitol was detected at $16 \mathrm{~h}$ or at logarithmic phase. Hence, probably model that could be concluded for OPEFB solid loading of $7.5 \%$, $10 \%$, and $15 \%$ was non-growth-associated product and if using 20\% OPEFB solid loading, its model was a mixed-growthassociated product.

Xylose concentration decreased significantly for 4 days of fermentation. Xylose consumed was used by yeast for both xylitol production and cell growth or maintenance. Besides, a decrease of xylitol was caused by xylitol oxidation by xylitol dehydrogenase $(\mathrm{XDH})$ to $\mathrm{D}$-xylulose and it was subsequently converted further to cell and used for NADH/NADPH regeneration [16]. Inhibition of xylitol formation also was led to xylose concentration. Substrate concentration was influenced by xylose reductase (XR) and XDH activity. Low initial xylose concentration could lead to not optimum enzyme production. On the contrary, high initial xylose concentration could affect to the difference of osmotic pressure between inside and outside of the cell [16].

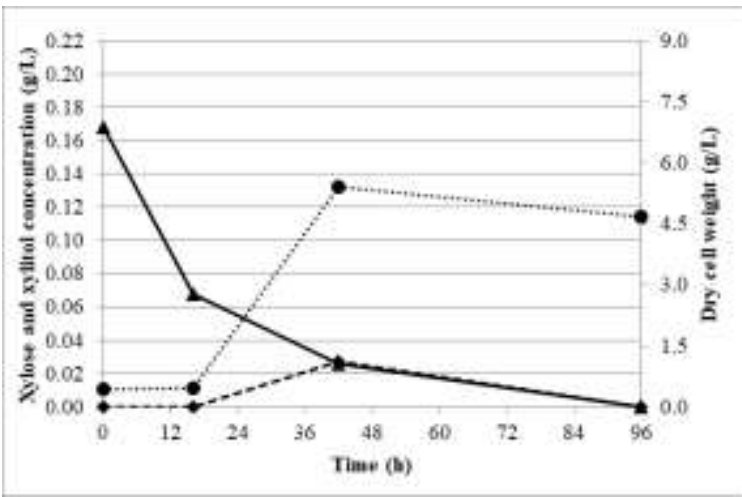

(b)

(a) 


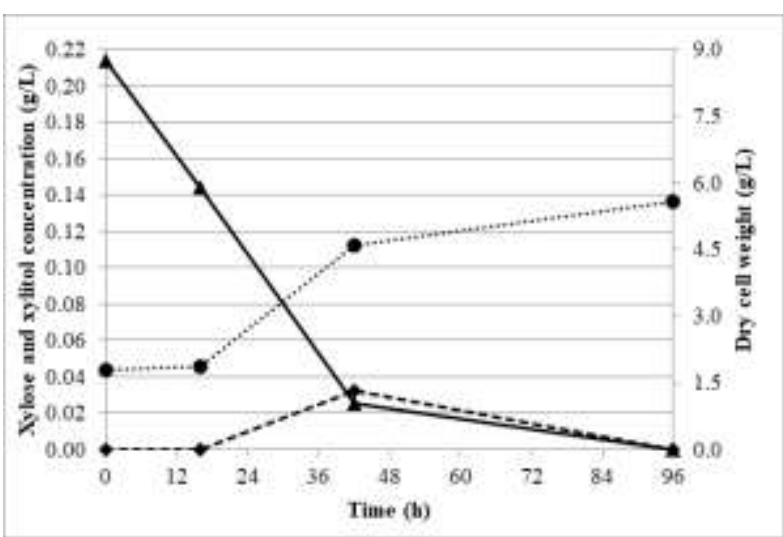

(c)

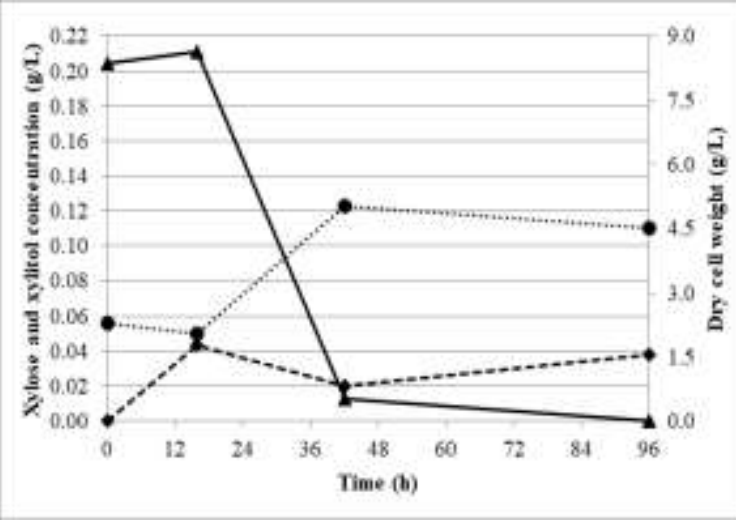

(d)

Figure 3. Profile of cell growth (round dot line with circles), xylose consumption (solid line with trangles), and xylitol production (square dot line with cloves) for $7.5 \%$ (a), $10 \%$ (b), 15\% (c), and 20\% (d) OPEFB solid loading concentration.

\subsection{Effect of Autohydrolysis on The Change of OPEFB Surface Structure}

The surface structure of OPEFB before treatment, after hydrolysis and fermentation were displayed in Fig. 4. The OPEFB had irregular outer surface, rough, rigid, and solid structure because its surface was covered with matrix layer composing of lignin and wax [17]. After hydrolysis, OPEFB outer surface was wrecked due to the effect of autohydrolysis. This result indicated that lignin on that surface was delignified [18]. Delignification by pretreatment could increase the porosity of OPEFB and enzyme access during enzymatic hydrolysis [19].

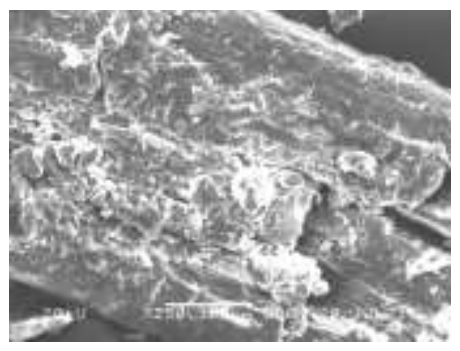

(a)

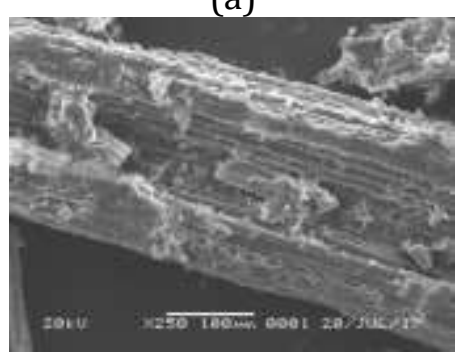

(b)

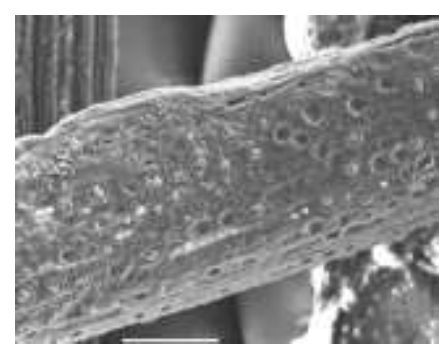

(c)

Figure 4. The change of OPEFB surface structure prior to treatment (a), after hydrolysis (b), and after fermentation (c)

Fermented OPEFB had structure showing that silica in OPEFB was still embedded on the surface. Silica contributed to the strength and rigidity of OPEFB [20]. Removal of silica on the surface could open a siliceous pathway and provided a more amorphous area of OPEFB, so the performance of hydrolysis increased [21].

\section{CONCLUSSIONS}

Simultaneous saccharification and fermentation was an effective and efficient way to produce xylitol from lignocellulose OPEFB. Various OPEFB solid loading from 7.5 to $20 \%$ gave a significant impact for xylose and xylitol released. The increase of solid loading could escalate the yield of xylose generated after hydrolysis. However, the higher solid loading was used for fermentation, the lower xylitol could be produced. Maximum xylitol obtained via SSF 
was $0.201 \mathrm{~g} / \mathrm{g}$ at the lowest solid loading (7.5\%), but the highest $\mu$ was $0.126 \mathrm{~h}^{-1}$ at the highest solid loading. The more severe condition of autohydrolysis was suggested for the next research to obtain optimum xylose yield. Autohydrolysis at $121^{\circ} \mathrm{C}$ for 15 minutes was not able to eliminate all silica bodies contributed to the strength and rigidity of OPEFB surface based on SEM analysis.

\section{ACKNOWLEDGEMENT}

This research was funded by Universitas Padjadjaran Research Grant and from Ministry of Research, Technology, and Higher Education of The Republic of Indonesia.

\section{REFERENCES}

[1] Mardawati, E. Purwadi, R. Kresnowati, M. T. A. P. Setiadi, T. Evaluation of the enzymatic hydrolysis process of oil palm empty fruit bunch using crude fungal xylanase. ARPN Engineering and Applied Sciences 12(18), 2017, 52865292

[2] Ni'mah, L. Ardiyanto, A. Zainuddin, M. Bioethanol production by yeast from oil palm fiber through method of pretreatment, acid hydrolysis, and fermentation. Info Teknik 16, 2015, 227-242

[3] Mardawati, E. Werner, A. Bley, T. Kresnowati, M. \& Setiadi, T. The enzymatic hydrolysis of oil palm empty fruit bunches to xylose. J Jpn Inst Energy 93, 2014, 973-978

[4] Saksono, B. Rare Sugars; Unexplored gifts. Bio Trends 1, 2006, 35-37

[5] Novia, A. Windarti Rosmawati. Bioethanol production from rice straw with method of ozonolysis pretreatment-simultaneous saccharification and fermentation (SSF). Jurnal Teknik Kimia 20, 2014
[6] Winkelhausen, E. Kuzmanova, S. Microbial conversion of D-xylose to xylitol, J Fer and Bioeng 86, 1998

[7] Mardawati, E. Wira, D. W. Kresnowati, M. Purwadi, R. and Setiadi, T. Microbial production of xylitol from oil palm empty fruit bunches hydrolysate: The effect of glucose concentration. J Jpn Inst Energy 94, 2015, 769-774

[8] Datta, R. Acidogenic fermentation of Lignocellulose-acid ield and conversion of components. Biotechnol Bioeng 23, 1981, 2167-217

[9] Mardawati, E. Kresnowati, M. T. A. P. Purwadi, R. Bindar, Y. Setiadi, T. Fungal Production of xylanase from oil palm empty fruit bunch via solid state fermentation. International Journal on Advance Science, Engineering and Information Technology, 8(6), 2018, 2539-2547

[10] Nobre, A. Duarte, L. C. Roseiro, J. C. Girio, F. M. A Physiological and enzymatic study of Debaryomyces hansenii growth on xylose and oxygenlimited chemostat. Appl Microbiol Biotechnol 59, 2002, 509-516

[11] Bailey, M. J. Biely P. Pountanen, K. Interlaboratory testing of methods for assay of xylanase activity. J Biotechnol 23, 1992, 257-270

[12] Wahyuni, A. Susilowati. Setyaningsih, R. Optimation xylitol production with variation of sugar cane bagasse hemicellulose hydrolysate concentration by Candida tropicalis. Biofarmasi 2, 2004, 29-34

[13] Purnamayani, R. Technology of compost production from oil palm empty fruit bunches. Balai Pengkajian Teknologi Pertanian (BPTP) 2013

[14] Margono. Cell growth kinetics of Bacillus sp. in glucose medium as carbon source and ammonium sulphate 
as nitrogen source. Ekuilibrium 2010, 57-61

[15] Faisal, A. Xylitol production from sugarcane bagasse by yeast producing xylose reductase (XR) enzyme. Bachelor Thesis. University of Indonesia, Depok, Indonesia, 2008

[16] Parajó, J. C. Dominguez, H. Dominguez, J. M. Biotechnological production of xylitol part I: Interest of xylitol and fundamentals of its biosynthesis. Bioresource Technology, 65, 1998, 191-211

[17] Hamzah, N. H. C. Markom, M. Harun, S;Hassan, 0 . The effect of various pretreatment methods on empty fruit bunch for glucose production. Malay J Anal Sci 20, 2016

[18] Ariffin, H. Hassan, M.A. Kalsom, M.S.U. Abdullah, N. Shirai, Y. Effect of physical, chemical and thermal pretreatments on the enzymatic hydrolysis of oil palm empty fruit bunch (OPEFB). J Trop Agric and Fd Sc 36, 2008

[19] Harun, N. A. F. Baharuddin, A. S. Zainudin, M. H. M. Bahrin, E. K. Naim, M. N. Zakaria, R. Cellulase production from treated oil palm empty fruit bunch degradation by locally isolated thermobifida fusca. Bioresouces 8, 2013

[20] Nascimento, D. C. O. Ferreira, A. S. Monteiro, S. N. Aquino, R. C. M. P. Kestur, S. G. Studies on the characterization of piassava fibers and their epoxy composites. Appl Sci Manuf 43, 2012, 353-362

[21] Omar, F. N. Mohammed, M. A. P. Baharuddin, A. S. Microstructure modelling of silica bodies from oil palm empty fruit bunch (OPEFB) fibres. Bioresource 9, 2014, 938-951 